International Journal of Business and Management Review

Vol.8, No.4, pp.1-10, July 2020

Published by ECRTD-UK

Print ISSN: 2052-6393(Print), Online ISSN: 2052-6407(Online)

\title{
STRUCTURAL EQUATION MODELING OF WORK-LIFE BALANCE, JOB EMBEDDEDNESS AND INTENT TO STAY: EVIDENCE FROM HEALTHCARE SECTOR
}

\author{
Egberi, Agbarha Kelvin PhD \\ Department of Business Administration and Management School of Business Studies, Delta \\ State Polytechnic, \\ Ozoro, Delta State, Nigeria. Email: kelvinegberi76@gmail.com
}

\begin{abstract}
Providing services to clients on a regular basis is a fundamental attribute of pharmaceutical personnel, particularly those in the hospitality department, nurses and resident doctors. Thus, sustaining a high-quality and stable healthcare services is vital for the healthcare sector. As for pharmaceutical companies' human resource management, how to effectively augment employee retention becomes imperative since it not only improve organizational performance but also lessens personnel costs. In this paper, we employed structural equation modeling to assess the nexus between job embedded-ness, organizational commitment and intent to stay with company. The paper utilized work-life balance as the moderating variable between organizational commitment and employee intent to stay. The research participants were pharmaceutical personnel who had worked with the Federal Medical Centres in Nigeria for at least 5years. Results revealed that job embedded-ness has significant and positive effect on organizational commitment and employee intent to stay with company. Moreover, organizational commitment mediates the link between job embedded-ness and employee intent to stay with company. Additionally, work-life balance moderates employees' intent to stay. In view of the findings, the study provides pharmaceutical companies with valuable management guidelines aimed at retaining employees.
\end{abstract}

KEYWORDS: work-life balance; employee retention; job embedded-ness; intent to stay; organizational commitment

JEL Classification: M1, M12, M19

\section{INTRODUCTION}

Quite a number of studies have been done on work-life balance in both developed and developing nations; however, there are few studies on work-life balance, job embedded-ness and employee intent to stay in Nigeria. According to Sakthivel and Selvarani (2011), work-life balance plays a vital role in shaping the attitudeof employees towardthe organization, particularly for highly skilled workers like pharmaceutical personnel, where the nature of job is typified with high stress, insecurities in the healthcare work environment, competition and whose commitment present a challenge to employers. According to Agha, Azmi and Irfan (2017) with the increasing levels of stress, competition and insecurities in the healthcare work environment, work-life balance concerns have become tremendously important.In view of this, employees in the healthcare sector are looking for ways that will assist them strike a balance between work and their personal life.For today's healthcare sector, how to heighten organizational commitment and boosttop employee retention is a foremost task (Hsiao-Ping, Chi-Ming, Meei-Ying \& Han-Shen, 2019; and Majumder, Giri\&Gangopadhyay, 2019). 
Print ISSN: 2052-6393(Print), Online ISSN: 2052-6407(Online)

In management literature, there is no one universally accepted meaning of what makes up worklife balance. Work-life balance as noted by Karand Misra(2013) is about unearthing a well-fit balance between work and life, and feeling happy with both work and commitment of family. In essence, work-life balance is the equilibrium between three (3) mechanisms, which are personal time, paid and unpaid work. Thus, it usually refers to one of the following dynamics: organizational support for dependent care, flexible work options and family or personal leave. Compared with other service sectors, the healthcare sector has more intensive customer interaction. Researchers have identified that work-life balance leads to positive organizational commitment (Hsiao-Ping, et al, 2019; Agha, et al, 2017; Yucel, 2017; Suresh \&Kodikal, 2017). Still, highemployee turnover rate in healthcare sector can compromise healthcare services by making servicequality erratic, plummetinghealthcare profitability, and lessening customers' satisfaction.

In employee turnover researches,researchers have utilized variables of organizational commitment and work satisfaction to elucidate employees' intent to leave and found that employees' intent to leave decreases bystirring work satisfaction and organizational commitment (Marut\&Wanno, 2014; Rashida, 2016; Oludayo, Falola, Ahaka\&Fatogun, 2018; and Rubina, Tasmia, Rabiul\&Ridoan, 2019). Nonetheless, these studies are futile in explaining why employees who are content with their jobs are still desirous of switching jobs. Thus by integrating the concept of job embedded-ness proposed by Lee, et al (2004), the nexus between job embedded-ness, organizational commitment and employee intent to stay can be better investigated. Consequent upon the above, this study assessed the nexus between job embeddedness and organizational commitment as well as that betweenorganizational commitment and employee intent to stay.

\section{REVIEW OF RELATED LITERATURE}

\section{Job Embedded-ness (JES)}

Job embedded-ness (JES) refers to integrative network systems where employees form indivisible bonds with people and other networks within the organization (Mitchell, et al, 2001).According to Cunningham, Fink and Sagas (2005) highlydensenetworks and sturdierbonds will make employeesmore unenthusiastic to switch jobs when they are offereda new one since they want to stayconnected in the indivisible network of their organizations. Prior studies showed that employees with greater jobembedded-ness are more enthusiastic to stay with their organizations (Cunningham, et al, 2005).

In human resource literature, there are three key variants of JES, which according to Mitchell et al (2001), encompassed organization fit, link and sacrifice.First, organization link refers to the extent of interaction and relatedness (formal or informal) between employees and organizations or other members of the workforce. Management literature indicates that sturdier links are equivalent to greater levels of job embedded-ness. Likewise, snowballing job embedded-ness reduces the chanceof employees quitting their jobs.Second, organization fit refers to the level of correspondence or fit of employees' style of life with their work as well as residential area. Third, sacrifice is the values and benefits lost when employees leave the organization (Holtom\&Inderrieden, 2006); thus, it is the employees' opportunity costs forquitting or leaving the job. 


\section{Organizational Commitment (ORC)}

Organizational commitment according to Hsiao-Pinget al (2019) is the psychological connections between employees and the organization. Langton and Robbins (2007) see ORCas a work attitude signaling the extent atwhich employees recognize themselves with the organization, organizational goals and extent to which they want to function effectively in the organization. Prior studies (Lee, 2004; Shreya\&Rajib,2014; and Suresh \&Kodikal, 2017) have shown thatreducing employees' work stress can result to improvement in organizational commitment, hence making employees to stay with their organization.

\section{Employee Intent to Stay (EIS)}

Employee intentto stay refers to the willingness and probability ofan employee not switching job by adopting a more positive attitude (Yoshimura, 2013). Employees' intent to stay centers on not only retaining talented employees, butprovokingthe right positive work attitude among employees of the organization.Extant literature (Shreya\& Rajib,2014; and Suresh \&Kodikal, 2017) suggests that there is a nexus betweenorganizational commitment, job embedded-ness and employee intent to stay with the organization.

\section{Link between JES, ORC and EIS}

Extant literature suggests a link between JES, ORC and EIS. For instance, a study by HsiaoPing et al (2019) found that job embedded-ness has a significant and positive impact on organizational commitmentand employee intent to stay while organizational commitment mediates the links between jobembedded-ness and employee intent to stay. Robinson et al(2014) revealed that organizational sacrifice have significant effects on organizational commitment. Prior studies indicated that employees' organization fit has a positive effect on job embedded-ness, and the higher the organization fit, the more positive this effect becomes. Given the position of extant literature, we therefore hypothesized that:

\section{$H_{1} a: \quad$ The higher the organization fit, the higher the organizational commitment}

$H_{1} b:$ The higher the organizational link, the higher the organizational commitment $H_{1}$ : The higher the organizational sacrifice, the higher the organizational commitment Furthermore, other studiessuch as Griffeth, Hom, and Gaertner (2000); and Perryer, Jordan, Firns and Travaglione (2010) found that organizational commitment is anprecursor variable of employees' intent to stay and, moreover, organizational commitment is positively related with employee intent to stay. Consequently, the higher the employees' organizational commitment, the higher their intent to stay. In view of this, we therefore hypothesized that:

\section{$\mathrm{H}_{2}: \quad$ The higher the organizational commitment, the higher the employee intent to stay}

Extant literature has revealed that job embedded-ness has a high explanatory power for employee intent to stay, and that these two (job embedded-ness and intent to stay) are positively correlated (Mitchell, et al, 2001; and Perryer, 2010). Thus, the greater the levels of job embedded-ness is, the more employees are not willing to quit or switch their organization. In view of the above position, we therefore hypothesized that:

$\mathrm{H}_{3} a: \quad$ The better the organization fit, the greater employee intent to stay

$\mathrm{H}_{3} b$ : The greater the levels of organizational link, the greater employee intent to stay 
Print ISSN: 2052-6393(Print), Online ISSN: 2052-6407(Online)

$\mathrm{H}_{3} c$ : The greater the organizational sacrifice, the greater employee intent to stay

Similarly, Robinson et al (2014) found that organizational sacrifice and job embedded -ness have significant effects on organizational commitment and employee intent to leave. More importantly, when employees are able to fit well in the organization, they are resolute to stay and committed to the organization. This implies that job embedded-ness influence organizational commitment, and that the greater the organizational commitment, the greater employees intent to stay.In view of the above, we therefore hypothesized that:

\section{$H_{4 a}$ Organization fit enhances employee intent to stay via organizational commitment $H_{4} b$ : Organization link enhances employee intent to stay via organizational commitment $\mathrm{H}_{4}$ : Organization sacrifice enhances employee intent to stay via organizational commitment}

\section{Moderating Effect of Work-life Balance}

Prior studies showed that work-life balance is fundamental in attracting and retainingtalented employees in the organization (Ojo, Salau\&Falola, 2014; and Suifan, Abdallah\&Diab, 2016). According to these studies, work-life balance is associated with organizational commitment and it affects employee intent to stay. In view of this, we hypothesized that:

$H_{5}$ : Work-life balance enhances the nexus between organizational commitment and employee intent to stay

\section{MATERIALS AND METHODS}

In this paper, convenience sampling was utilized to survey pharmaceutical personnel with at least 5years of work experience inFederal Medical Centres (FMCs) in Nigeria. We distributed four hundred (400) questionnaires and three hundred and eight-six (386) were returned.However, after eliminating one hundred and twenty-one(121) invalid questionnaires, two hundred and sixty-five(265) valid questionnaires remained for a valid return rate of $68.7 \%$. Among the pharmaceutical personnel in FMCsthat completed the survey, 101(38.1\%) were men and $164(61.9 \%)$ were women. Furthermore, most pharmaceutical personnel were from hospitality management $(\mathrm{N}=136)$, followed nurses $(\mathrm{N}=79)$ and resident doctors $(\mathrm{N}=50)$.

In view of the review of related literature, Figure 1 captures the research framework for assessing the link between job embedded-ness(organizations fit, link and sacrifice), organizational commitment, employee intent to stay and work-life balance of pharmaceutical personnel in Nigerian FMCs. Within this framework, the independent variables of the study encompassed organizations fit, sacrifice and link; dependent variable is employee intent to stay; moderator variable, work-life balance and mediator variable, organizational commitment moderator variable, work-life balance and mediator variable, organizational commitment 


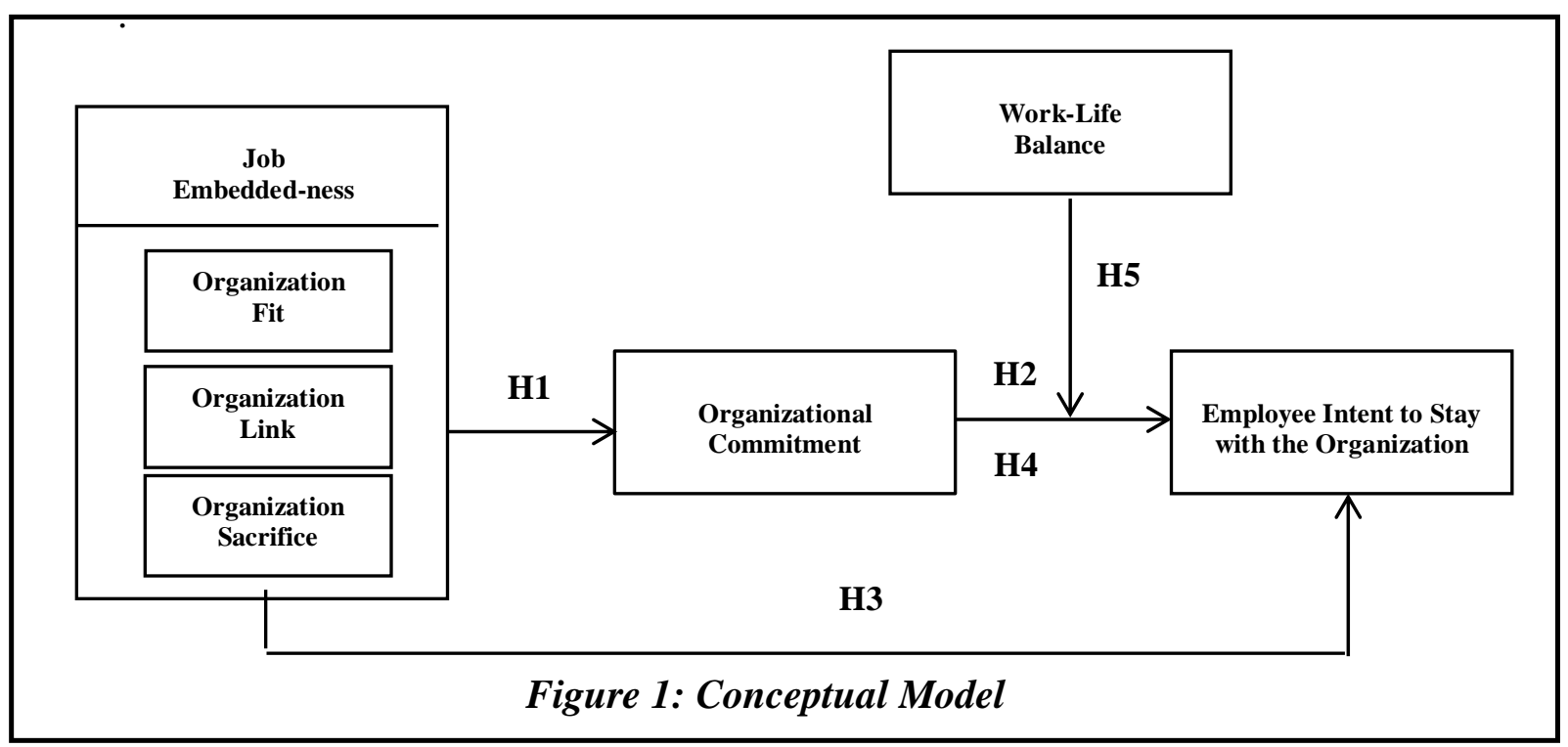

The questionnaire entails 10-item scale adapted from the works of Crossley, Bennett, Jex and Burnfield (2007); and Holtom and Inderrieden (2006). In these studies, the reliability results of Cronbach'salpha $(\alpha)$ for organization link, fit and sacrifice scales ranged from 0.85 to 0.89 . On the other hand, the 6-item scale of organizational commitment was adapted from the works of Robinson et al (2014) and Mitchell, et al (2001) which yielded a Cronbachalpha $(\alpha)$ of 0.85 . Moreover, the 5-item scale of employee intent to stay with the organization was adapted from the work of Coetzee and Stoltz(2015), with a Cronbach Alpha $(\alpha)$ of 0.95 while 11-item scale of work-life balance was adapted from the work of Hayman (2005), yielding a Cronbach Alpha $(\alpha)$ of 0.97 . Noteworthy is the fact that all the Cronbach Alpha coefficients exceed 0.70, which according to Nunnally (1978) is reliable for a research instrument. Also, each questionnaire items were built on a 7-point Likert scale varying from 1(SD) to 7(SA).To ascertainthe link between job embedded-ness(organization fit, link and sacrifice), organizational commitment, employee intent to stay and work-life balance, confirmatory factor as well as structural equation modeling (SEM) analyses wereperformed via STATA 13.0 statistical software.

\section{RESULTS}

\section{Descriptive Results}

Table 1: Mean, Standard Deviation, Cronbach Alpha, Composite Reliability (CR), Average Variance Extracted (AVE) and Correlations of Variables

\begin{tabular}{|c|c|c|c|c|c|c|c|c|c|c|}
\hline Variables & Mean & SD & $\mathbf{C R}$ & AVE & 1 & 2 & 3 & 4 & 5 & 6 \\
\hline Organization fit & 5.3739 & 0.8484 & 0.96 & 0.58 & $(\mathbf{0 . 9 3 5 )}$ & & & & & \\
\hline Organization link & 5.9745 & 1.2726 & 0.73 & 0.45 & $0.272 * *$ & $(\mathbf{0 . 8 8 9})$ & & & & \\
\hline Organization sacrifice & 5.2773 & 1.0553 & 0.95 & 0.66 & $0.756 * *$ & $0.272 * *$ & $(0.907)$ & & & \\
\hline Organizational comt. & 5.7236 & 0.8978 & 0.98 & 0.75 & $0.487 * *$ & $0.148 * *$ & $0.487 * *$ & $(0.896)$ & & \\
\hline Work-life balance & 5.9756 & 0.8988 & 0.95 & 0.56 & $0.365 * *$ & $0.404 * *$ & $0.364 * *$ & $0.438 * *$ & $(0.971)$ & \\
\hline $\begin{array}{l}\text { Employee intent to } \\
\text { stay }\end{array}$ & 4.6820 & 1.6643 & 0.98 & 0.80 & $0.594 * *$ & $0.237 * *$ & $0.584 * *$ & $0.741 * *$ & $0.517 * *$ & $(0.951)$ \\
\hline
\end{tabular}

Source: Fieldwork, 2020; N=265; **p<0.01; Bold numbers inparentheses(diagonally)are reliability of variable 
Print ISSN: 2052-6393(Print), Online ISSN: 2052-6407(Online)

Presented in Table 1 is the descriptive result from our analysis, which encompassed mean, standard deviation, Cronbach alpha, composite reliability and correlation matrix. In line with our hypotheses, the correlations amongst organizations fit, link, sacrifice, organizational commitment, work-life balance and employee intent to stay with the organization were all significant. The CronbachAlpha $(\alpha)$ of each metrics was greater than 0.80 , indicating a good reliability. The composite reliability of variables ranged from 0.73 to 0.98 , indicating that the model had good internal consistency. Also, the average variance extracted for each factors was between 0.45 and 0.80 , which is greater than the benchmark of 0.3 as recommended by Fornell and Larcker(1981).

\section{Structural Equation Modeling (SEM) Results}

We applied the structural equation modeling (SEM) to establish the path relationships among the investigated constructs. The results revealed that the measurement model offered an absolute fit to data $\left(\mathrm{X}^{2} / \mathrm{df}=3.96\right.$, goodness of fit statistic $(\mathrm{GFI})=0.958$, adjusted goodness of fit statistic $(\mathrm{AGFI})=0.963$, comparative fit index $(\mathrm{CFI})=0.966$, root mean square residual $(\mathrm{RMR})$ $=0.033$, root mean square error of approximation $($ RMSEA $)=0.076)$. The GFI, AGFIand CFI exceeded the recommended ceiling of 0.90 , and RMSEA and standardized root mean square residual (SRMR) values were below the benchmark value of 0.08 . This implies that the approach employed for modeling the investigated variables fits properly. Moreover, the research hypotheses results of the model data are presented in in Figure 2 and Table 2.

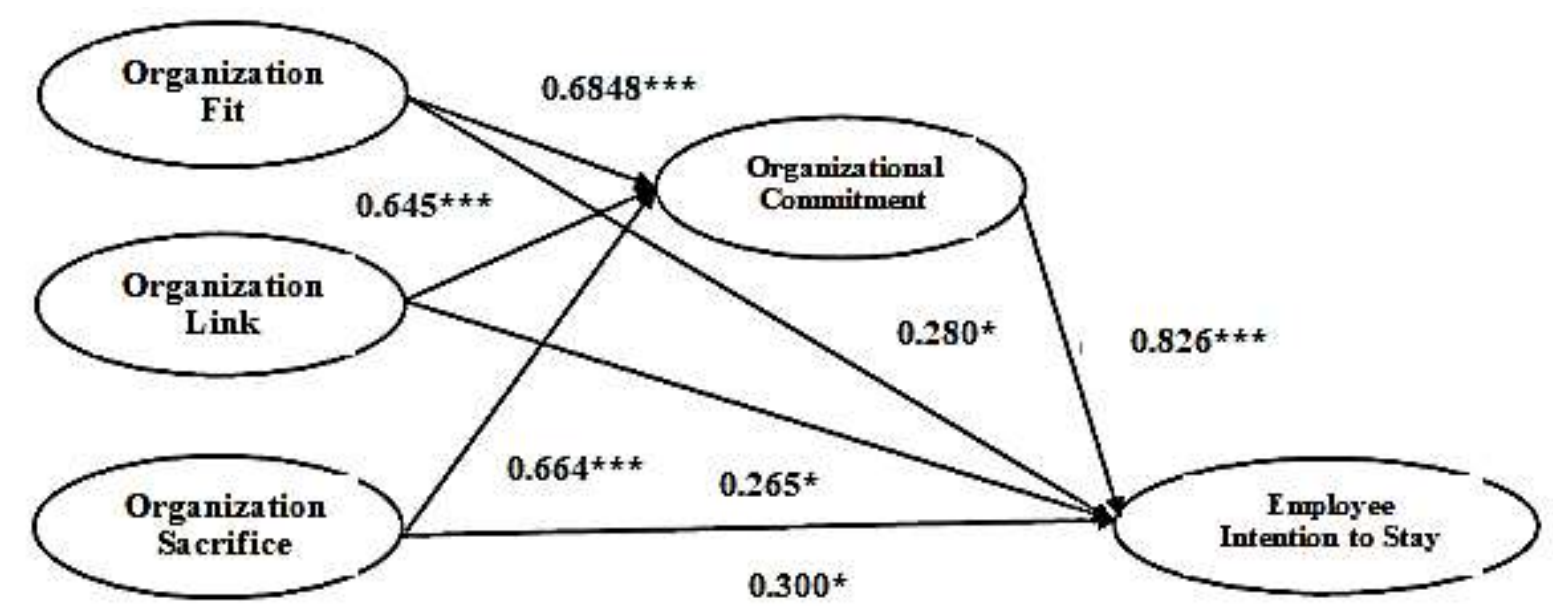

Figure 1: Results of the Hypothesized Model.*p<0.05; ***p<0.001.

Given the SEMresult, hypotheses $\mathrm{H}_{1} \mathrm{a}-\mathrm{H}_{1} \mathrm{c}$ were supportedimplying that organization fit, link and sacrifice of pharmaceutical personnel are significantly and positively related with organizational commitment. In terms of pathway coefficients, $\gamma 11$ is $0.6848(p<0.001), \gamma 12=$ $0.645(\mathrm{p}<0.001)$ and $\gamma 13=0.664(\mathrm{p}<0.001)$ respectively. These findings suggest that enhancing pharmaceutical personnel behaviouras related to organization fit, link and sacrifice is vital for hospitality management, nurses and resident doctors to elicit organizational commitment in FMC. As for levels of reinforcement, organization fit is the greatest, accompanied by sacrifice and link. Besides, hypothesis $\mathrm{H}_{2}$ was supported; indicating that pharmaceutical personnel' commitmentand intent to stay with FMC are significantly and positively related. Moreover, the 
Print ISSN: 2052-6393(Print), Online ISSN: 2052-6407(Online)

pathway coefficient $\beta 21$ is $0.826 \quad(\mathrm{p}<0.001)$, showing that enhancing pharmaceutical personnel's commitment behavior will positively reinforce their intention to stay with FMC.

Furthermore, hypotheses $\mathrm{H}_{3} \mathrm{a}-\mathrm{H}_{3} \mathrm{c}$ were supported; indicating that pharmaceutical personnel's organization fit, link and sacrifice are significantly and positively related with their intention to stay with FMC. The pathway coefficient $\gamma 21$ is $0.280(\mathrm{p}<0.05), \gamma 22=0.265(\mathrm{p}<0.05)$ and $\gamma 23=0.300(p<0.05)$, suggesting that pharmaceutical personnel's should enhance organization fit, link and sacrifice behaviourin order to positively reinforce their intention to stay with FMC.As for levels of reinforcement, organization sacrifice is highest, accompanied by fit and then link.Additionally, results showed a significant and positive link between job embeddednessand employee intent to stay with FMC. Thus, this paper further assessed whether organizational commitment could alter the effect of job embedded-nesson employee intent to stay.

Table 2: The Model's Standardized Regression Weights, $t$-Values and Hypothesis

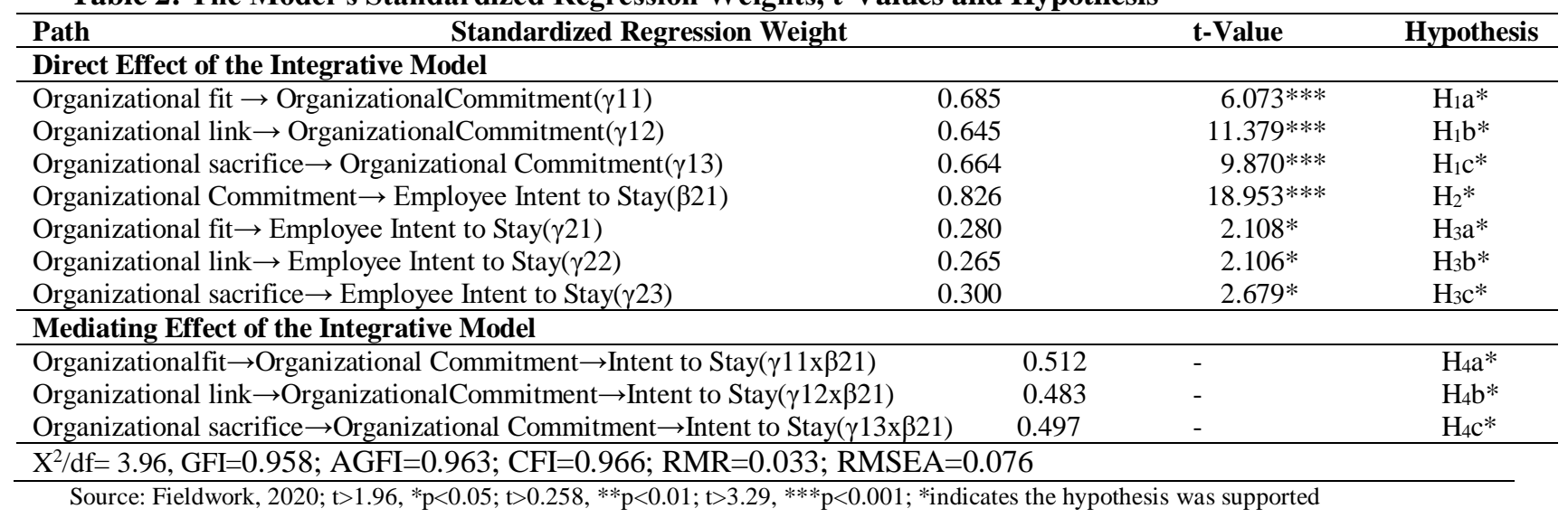

Table 2 shows that the direct effect of organization fit on employee intent to stay is 0.280 ; with organizational commitment, the indirect effect between organization fit and employee intent to stay $(\gamma 11 \times \beta 21)$ became $0.512(\mathrm{p}<0.001)$. Owing to the fact that the indirect effect was greater than the direct effect, a mediating effect ensued, and hypothesis $\mathrm{H}_{4}$ a was supported. Moreover, the direct effect between organization link and employee intent to stay with FMC is 0.265; with organizationalcommitment, indirect effect between the two $(\gamma 12 \times \beta 21)$ became $0.483(p<0.001)$. In view of the fact that the indirect effect was higher than direct effect, a mediating effect ensued; hence, hypothesis $\mathrm{H}_{4} \mathrm{~b}$ was supported. Finally, the direct effect between organization sacrifice and employee intent to stay with FMC is 0.300; with organizational commitment, indirect effect between the two $(\gamma 13 \times \beta 21)$ became $0.497(\mathrm{p}<0.001)$ while indirect effect was higher than direct effect, a mediating effect occurred; thus hypothesis $\mathrm{H}_{4} \mathrm{c}$ was supported. 
Print ISSN: 2052-6393(Print), Online ISSN: 2052-6407(Online)

Validating the Mediating Effects

Table 3: Hierarchical Regression Results

\begin{tabular}{|l|l|l|l|}
\hline \multicolumn{4}{|l|}{ Employee Intent to Stay with FMC } \\
\hline Variables & Model 1 & \multicolumn{1}{l|}{ Model 2 } & Model 3 \\
\hline Step 1: Independent Variable & 0.826 & 0.269 & 0.144 \\
\hline Organizational Commitment & & $0.662^{* * *}$ & $0.384 * * *$ \\
\hline Step 2: Moderator Variable & & & $0.677 * * *$ \\
\hline Work-life Balance & & 0.265 & 0.286 \\
\hline Step 3: Interaction Variable & 0.183 & 0.082 & 0.021 \\
\hline Organizational Commitment x Work-life Balance & & $39.297 * * *$ & $27.427 * * *$ \\
$\mathrm{R}^{2}$ & $49.354 * * *$ & \\
$\Delta \mathrm{R}^{2}$ &
\end{tabular}

The interactive effect of organizational commitment, employee intent to stay and work-life balance with FMC, Nigeria was presented in Table 3. The hierarchical regression was utilizedto assess the moderating effect of work-life balance on the nexus between organizational commitment and employee intent to stay with FMC. The regression model 3 revealed that the product oforganizational commitment and work-life balance augmented the coefficient of determination $\mathrm{R}^{2}$ to 0.286 , resulting in a variation $\left(\Delta \mathrm{R}^{2}\right)$ of 0.021 . Besides, the regression coefficient of organizational commitment $\mathrm{x}$ work-life balance increased the level of significance $(\beta=0.677, p<0.001)$, indicating that work-life balance has a moderating effect on the nexus between organizational commitment and employee intent to stay with FMC. This implies that when pharmaceutical personnel perceived work-life balance as good, the effect of organizational commitment and employee intent to stay with FMC is enhanced. Also, when work-life balance is perceived as bad, this augment the effect of organizational commitment and employee intent to stay with FMC. On the overall, work-life balance (when perceived as good by pharmaceutical personnel) could more accurately predict the effect of organizational commitment and employee intent to stay with FMC than when work-life balance is perceived as bad.

\section{CONCLUSION AND RECOMMENDATIONS}

In this paper, we investigated that organizational commitment has the utmost potent effect on employee intention to stay andhence a core task for Nigerian healthcare to improve pharmaceutical personnel's organizational commitment to augment their intent to stay. As a matter of fact, this paper has some insightful revelations. The paper offers pharmaceutical personnel with room for development and shows that pharmaceutical personnel care about whether their ideas are accepted by Federal Medical Centre (FMC) in Nigeria.

Consequently, the healthcare industry should assist healthcare personnel unbridle their talent and beaware of their desire for proficiencyadvancement. For healthcare personnel with better performance to their colleagues, the healthcare industry should allow them learn high-level work and ensure that their remuneration will be better if they stay with the organization. Besides, inspiringemployees with suboptimal performance is vital to heighten their trust in the organization towards realizing their personal goals. As a matter of fact, healthcare personnel will be more keen to stay since they are aware that their needs can be better realized in their organizations. More importantly, the paper established that work-life balance had a moderating 
Print ISSN: 2052-6393(Print), Online ISSN: 2052-6407(Online)

effect on the nexus between organizational commitment and employee intent to stay. Hence, human resource department of pharmaceutical companies should assist employees in growing a good work-life balance. This will further help them stay on the job and be absolutely committed to put in their best in the work environment.

\section{REFERENCES}

Agha, K., Azmi, F.T. \&Irfan, A. (2017).Work-life balance and job satisfaction: An empirical study focusing on higher education teachers in Oman.International Journal of Social Science and Humanity, 7(3), 164-171

Coetzee, M., \&Stoltz, E. (2015).Employees' satisfaction with retention factors: Exploring the role of career adaptability.Journal of Vocation Bheaviour, 89, 83-91.

Crossley, C.D., Bennett, R.J., Jex, S.M., \&Burnfield, J.L. (2007).Development of a global measure of job embeddedness and integration into a traditional model of voluntary turnover.Journal of Applied Psychology, 92, 1031.

Cunningham, G.B., Fink, J.S. \&Sagas, M. (2005).Extensions and further examination of the job embeddedness construct. Journal of Sport Management, 19, 319-335.

Fornell, C., \&Larcker, D.F. (1981).Evaluating structural equation models with unobservable variables and measurement error.Journal of Marketing Research, 18, 39-50.

Griffeth, R.W., Hom, P.W., \&Gaertner, S. (2000). A meta-analysis of antecedents and correlates of employee turnover: Update, moderator tests, and research implications for the next millennium. Journal of Management, 26, 463-488.

Hayman, J. (2005). Psychometric assessment of an instrument designed to measure work life balance. Research in Practical Human Resource Management, 13, 85-91.

Holtom, B.C. \&Inderrieden, E.J. (2006). Integrating the unfolding model and job embeddedness model to better understand voluntary turnover. Journal of Management Issues, 18, 435-452.

Hsiao-Ping, C., Chi-Ming, H., Meei-Ying, L. \& Han-Shen, C. (2019).Examining the moderating effects of work-life balance between human resource practices andintention to stay.Sustainability, 11(2019), 1-15

Kar, S. \&Misra, K.C. (2013). Nexus between work life balance practices and employee retention-the mediating effect of a supportive culture. Asian Social Science, 9(11), 6369.

Khan, S. \& Agha, K. (2013).Dynamics of the work-life balance at the firm level: Issues and challenges.Journal of Management Policy and Practice, 14(4), 103-114.

Langton, N. \&Robbins, S.P. (2007).Organizational behaviour: Concepts, controversies, applications;USA: Pearson Prentice Hall: Upper Saddle River.

Lee, T.W., Mitchell, T.R., Sablynski, C.J., Burton, J.P., \&Holtom, B.C. (2004).The effects of job embeddedness onorganizational citizenship, job performance, volitional absences, and voluntary turnover.Academic Management Journal, 47(2004), 711-745

Majumder, J., Giri, A. \&Gangopadhyay, S. (2019).Factors affecting work life balance of employees in indian manufacturing companies: An empirical analysis using structural equation modeling (SEM). International Journal of Innovative Technology and Exploring Engineering, 8(7), 1551-1555 
Print ISSN: 2052-6393(Print), Online ISSN: 2052-6407(Online)

Marut, M. \&Wanno, F. (2014). Structural equation model of variables affecting turnover intentions on Bangkok's information technology career professionals. Research Journal of Business Management, 8(4), 453-463 doi: 10.3923/rjbm.2014.453.463

Mitchell, T.R., Holtom, B.C, Lee, T.W., Sablynski, C.J., \&Erez, M. (2001).Why people stay: Using job embeddedness to predict voluntary turnover.Academy of Management Journal, 44, 1102-1121.

Nunnally, J. (1978). Psychometric theory. New York, USA: McGraw-Hill Publishers Limited.

Ojo, I.S., Salau, O.P., \&Falola, H.O. (2014).Work-life balance practices in Nigeria: A comparison of three sectors. WLBPracticNigeria, 6, 3-14.

Oludayo, O.A., Falola, H.O., Ahaka, O. \&Fatogun, D. (2018). Work-life balance initiative as a predictor of employees' behavioural outcomes. Academic of Strategic Management Journal, 17(1), 1-17

Perryer, C., Jordan, C., Firns, I., \&Travaglione, A. (2010).Predicting turnover intentions: The interactive effects of organizational commitment and perceived organizational support.Management Research Review 33, 911-923.

Rashida, A.B. (2016). A structural equation model-II for work-life balance of IT professionals in Chennai.Serbian Journal of Management, 11(1), 141-148

Robinson, R.N.S., Kralj, A., Solnet, D.J., Goh, E., \&Callan, V. (2014).Thinking job embeddedness not turnover: Towards a better understanding of frontline hotel worker retention.International Journal Hospital and Management, 36, 101-109.

Rubina, E., Tasmia, A., Rabiul, H.D. \&Ridoan, K. (2019).Improving work life balance: A study on employees in private commercial banks of Bangladesh. Journal of Business and Management, 21(5), 1-12

Sakthivel, R. \&Selvarani, K. (2011).Work-life balance reflection on employee satisfaction.Serbian Journal of Management, 6(1), 85-96

Shreya, G. \&Rajib, L.D. (2014).Effects of stress, LMX and perceived organizational support on service quality: Mediating effects of organizational commitment.Journal of Hospitality Tourism and Management, 21, 64-75.

Suifan, T.S., Abdallah, A.B., \&Diab, H. (2016). The influence of work life balance on turnover intention in private hospitals: The mediating role of work life conflict.European Journal of Business Management, 8, 126-139.

Suresh, S. \&Kodikal, R. (2017).SEM approach to explore work life balance: A study among nurses of multispecialty hospitals.Journal of Management, 1(1), 1-18

Yoshimura, K.E. (2013). Employee traits, perceived organizational support, supervisory communication, affective commitment, and intent to leave: Group difference.Master's Thesis, North Carolina State University, North Carolina, NC, USA, 13 November.

Yucel, D. (2017). Work-family balance and marital satisfaction: The mediating effects of mental and physical health.Society and Mental Health, 7(3) 175-195. doi: $10.1177 / 2156869317713069$ 